Int. J. Dev. Biol. 56: 363-368 (2012)

doi: $10.1387 / \mathrm{ijdb} .120008 \mathrm{ah}$

\title{
An immunohistochemical analysis of Rab27B distribution in fetal and adult tissue
}

\author{
AN HENDRIX*,\#,1,2, KATHLEEN LAMBEIN*,\#,3, WENDY WESTBROEK ${ }^{4}$, MIGUEL C. SEABRA ${ }^{5,6,7}$, VERONIQUE \\ COCQUYT' ${ }^{2}$, PATRICK PAUWELS ${ }^{3,9}$, MARC BRACKE ${ }^{1}$, CHRISTIAN GESPACH ${ }^{8}$ and OLIVIER DE WEVER ${ }^{1}$

\begin{abstract}
${ }^{1}$ Laboratory of Experimental Cancer Research, Department of Radiation Oncology and Experimental Cancer Research, ${ }^{2}$ Department of Medical Oncology and ${ }^{3}$ Department of Pathology, Ghent University Hospital, Ghent, Belgium, ${ }^{4}$ Medical de Lisboa, Lisbon, Portugal, ${ }^{7}$ Instituto Gulbenkian de Ciência, Oeiras, Portugal, ${ }^{8}$ INSERM U938 Molecular and Clinical Oncology, Université Pierre et Marie Curie-Paris Paris VI, Faculté de Médecine, Paris, France
\end{abstract} \\ Genetics Branch, National Human Genome Research Institute, Bethesda, MD, USA, ${ }^{5}$ Molecular Medicine, National Heart \\ and Lung Institute, Imperial College London, London, UK, ${ }^{6}$ CEDOC, Faculdade de Ciências Médicas, Universidade Nova \\ ${ }^{9}$ Department of Pathology, Antwerp University, Antwerp, Belgium
}

\begin{abstract}
Regulated secretory pathways coordinated by small Rab GTPases are critically involved in intercellular communications. Here, we report the expression and localization of Rab27B in developing and differentiated epithelial human tissues by immunohistochemistry. Rab27B is poorly expressed in fetal tissues suggesting that several developmental mechanisms involved in epithelial differentiation and functions are mediated by other secretory Rab GTPases, such as Rab27A or Rab3 family members. In adult tissues, Rab27B is expressed in a wide variety of differentiated secretory epithelial cells, including those lining the salivary gland, gastrointestinal, mammary and prostate tracts. The complex pattern of Rab27B expression indicates that dysregulation of Rab27B-mediated secretion may have profound implications for disease pathology.
\end{abstract}

KEY WORDS: development, small GTPase, exocytosis, secretory Rab, Rab27

Secretion is a fundamental biological activity of all eukaryotic cells by which they release substances in the extracellular space. The process demands the exquisite interplay between a number of different protein classes, secretory vesicles, the plasma membrane and the eliciting calcium signal. Different types of secretory vesicles exist and their function depends from cell type to cell type. Electron density provides an elementary classification in dense core or light core vesicles. Rabs, small GTP-binding proteins, are the major regulators of vesicular transport (Stenmark, 2009). Like other small GTPases, Rab proteins are functioning as molecular switches using an enzymatic cycle of GTP-binding, hydrolysis and dissociation for their activation or inactivation (Vetter and Wittinghofer, 2001). Posttranslational addition of one or two geranylgeranyl groups allows the Rab protein to anchor vesicle membranes (Leung et al., 2006) and to interact with different effectors (Grosshans et al., 2006).

Six members of the Rab family are associated with various secretory vesicles and are described as drivers of regulated secretion: Rab27A/B and Rab3A/B/C/D (Fukuda, 2008). Detailed studies in animal models identified Rab27B on pituitary endocrine granules (Zhao et al., 2002), dense granules in platelets (Barral et al., 2002, Tolmachova et al., 2007) and megakaryocytes (Tiwari et al., 2003), urothelial fusiform vesicles (Chen et al., 2003), parotid and pancreatic acinar zymogen granules (Chen et al., 2004, Imai et al., 2004), mast cell secretory granules (Mizuno et al., 2007), gastric parietal tubular vesicles (Suda et al., 2011), and secretory granules in alveolar epithelial type II and Clara cells (Bolasco et al., 2011). Furthermore, Rab27B is abundantly expressed in stomach acid-secreting parietal cells and mucus cells, as shown in a transgenic mouse model expressing beta-galactosidase under the Rab27B promoter (Gomi et al., 2007). Aberrant implementation of Rab27B-mediated secretion contributes to cancer progression. Rab27B promotes invasive growth and metastasis in estrogen receptor (ER)-positive breast cancer cell lines. Increased expression of Rab27B, but not Rab3D and Rab27A, is associated with poor-prognosis breast tumors (Hendrix et al., 2010b, Hendrix et al., 2010c).

Abbreviations used in this paper: ER, estrogen receptor.

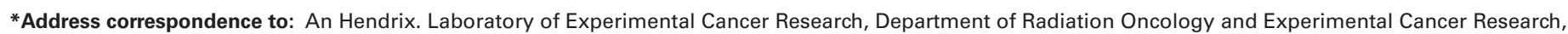
Ghent University Hospital, De Pintelaan 185, 9000 Gent, Belgium. Tel.: +32-9-332-3008. Fax: +32-9-332-4991. Email: an.hendrix@ugent.be

\# Note: Both authors contributed equally to this paper. 
In this manuscript, we examined the expression status and the cellular localization of Rab27B in fetal and adult normal human tissues and discuss the observations in relation to the presumptive functions of Rab27B and other secretory Rab GTPases.

\section{Results}

\section{Rab27B in human fetal tissues}

During embryological development, light or dense core secretory vesicles deliver morphogens such as basic fibroblast growth factor and wingless/wnt to form a concentration gradient across the developing tissue. Rab27B protein is detected at low levels in fetal tissues at 17-24 weeks of gestation. Rab27B is barely detectable in the cytoplasm of mucosal gastric epithelial cells, the small intestine and gall bladder (Fig. 1 A,B,D). A heterogeneous Rab27B distribution is observed in the exocrine pancreas (Fig. $1 \mathrm{E})$. Rab27B is also detected in oocytes and testicular Leydig cells (Fig. $1 \mathrm{~F}, \mathrm{G}$ ). Rab27B is not detected in colon, ovarian epithelial cells, respiratory tract epithelia and in smooth, skeletal and cardiac muscle cells (Fig. 1 C,F,H,I and data not shown). The Rab3 subfamily mediates membrane fusion throughout embryogenesis. Neurogenin 3 commits pancreatic progenitors to an islet cell fate, through Rab3B expression. Rab3B is localized to the cytoplasm
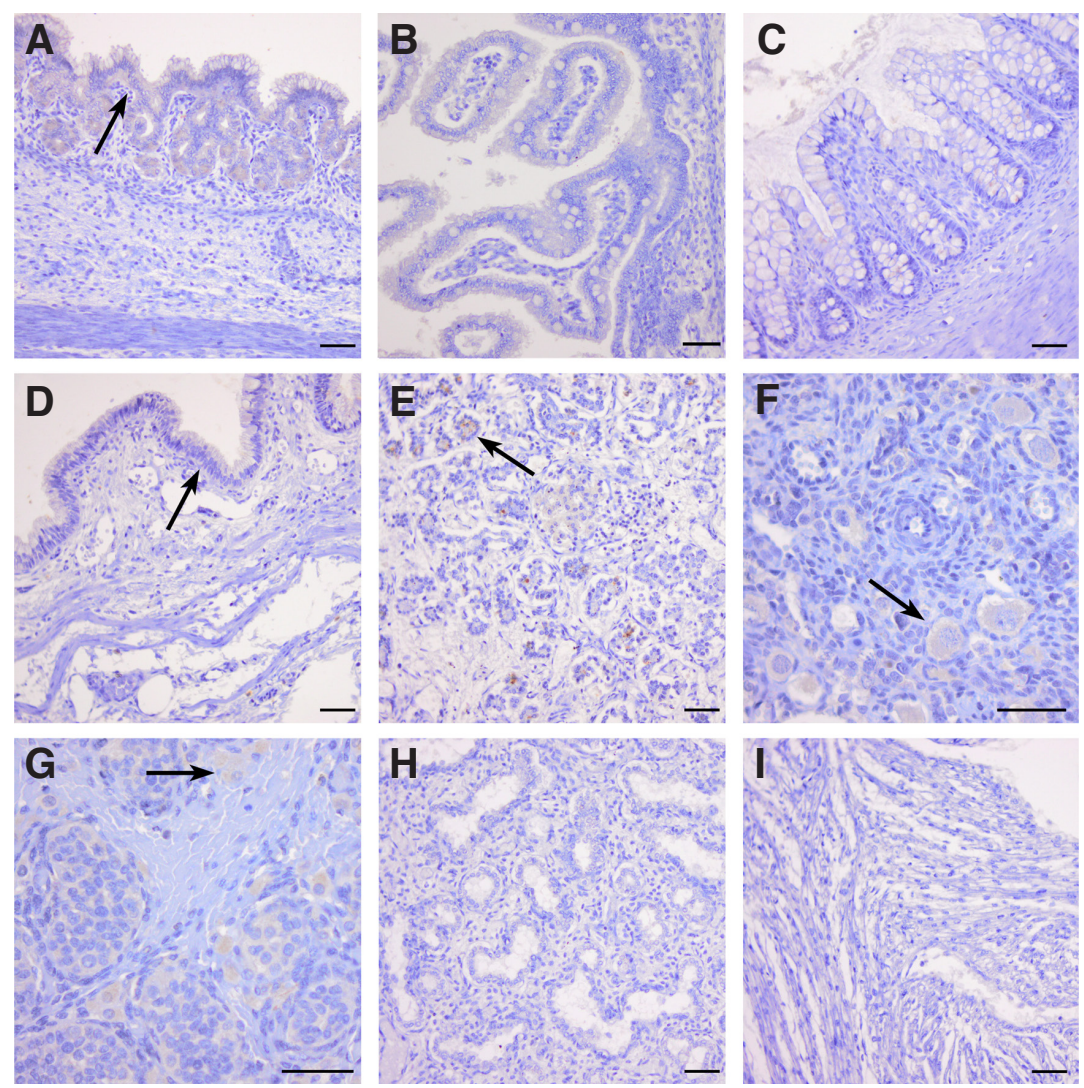

Fig. 1. Immunohistochemical analysis of Rab27B in fetal tissues at 17-24 weeks of gestation. (A) Stomach. (B) Small intestine. (C) Colon. (D) Gall bladder. (E) Pancreas. (F) Ovary. (G) Testis. (H) Lung. (I) Cardiac muscle cells. In (A,D) arrows indicate Rab27B staining in the surface epithelium. In (E) arrow indicates Rab27B positive exocrine cells. Arrows in (F,G) indicate Rab27B expression in oocytes and Leydig cells, respectively. Scale bar: $50 \mathrm{um}$. in human pancreatic $\beta$-cells during fetal and postnatal development (Piper Hanley et al., 2010). Rab3 proteins play two distinct stimulating roles for large dense-core vesicle fusion in embryonic chromaffin cells, by facilitating vesicle biogenesis and stabilizing the primed vesicle state (Schonn et al., 2010). In the sea urchin Rab3 is specifically enriched in regions of the embryo with active secretory roles such as the apical and basal aspects of cleaving lastomeres, indicative of bidirectional secretion into the extraemonic environment and blastocoel. Elevated levels of Rab3 were teins to enable mobility by mediating the secretion of enzymes that break adhesion to neighboring cells and the extracellular matrix

\section{Rab27B in human adult tissues}

\section{Exocrine activities}

In salivary glands, Rab27B is detected in epithelial cells of the serous-type acini and those lining the striated ducts (Fig. 2A). In acinar cells, identified by dense zymogen granules, Rab27B is detected at the epithelial cell-cell contacts. In striated ducts, Rab27B staining is strikingly polarized at the luminal pole. Salivary gland acinar cells secrete serous saliva containing amylase. Rab27B regulates amylase release from rat parotid acinar cells (Imai et al., 2004). Rab3D has been identified on secretory vesicles in parotid glands (Ohnishi et al., 1996).

The tall columnar epithelial cells of the gall bladder show abundant Rab27B expression concentrated at the luminal surface (Fig. 2B). Rab27B transports fusiform vesicles, which deliver uroplakin proteins to the apical pole of urothelial umbrella cells (Chen et al., 2003). Smooth muscle fibers are Rab27B negative, except for occasionally infiltrated mast cells.

In the acinar cells of the pancreas Rab27B shows a diffuse and granular cytoplasmic localization (Fig. 2C). The pancreatic ducts express luminal Rab27B. This network is connected with the exocytosis of zymogen granules and digestive enzyme secretion (Chen et al., 2004). Rab3D is present on zymogen granules (Ohnishi et al., 1997). The pancreatic endocrine islets show a weak Rab27B staining (not shown). In contrast, the close homologue Rab27A is found associated with insulin-containing secretory granules of pancreatic $\beta$-cells. Of note, siRNA-mediated Rab27A depletion impairs exocytosis of insulin granules triggered by glucose (Tolmachova et al., 2004, Waselle et al., 2003, Yi et al., 2002).

\section{Protective mucus barriers}

In the alimentary tract and lungs, Rab27B is found highly expressed at the epithelial surface of mucus secreting cells. These cells protect the epithelial surface from mechanical, chemical, enzymatic, and microbial damages.

In the gastric corpus Rab27B is concentrated at the 

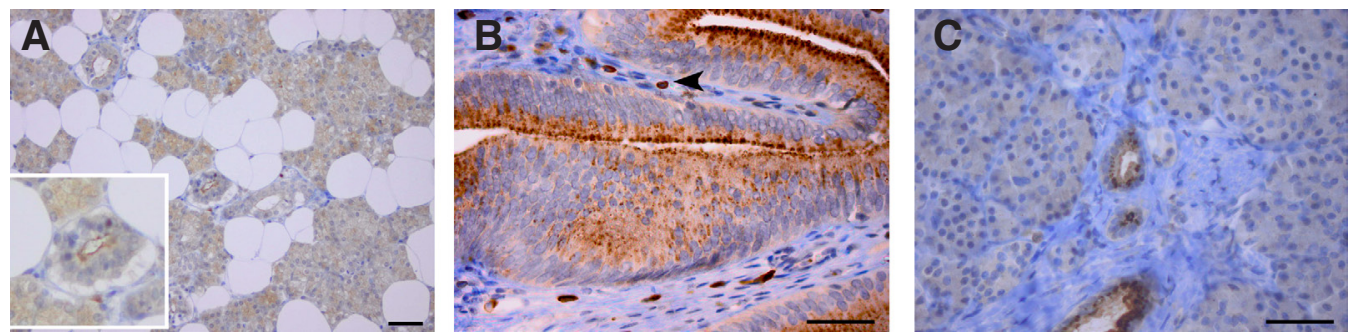

Fig. 2. Rab27B immunostaining in adult tissues with exocrine activity. (A) Salivary gland. Inset: Luminal Rab27B expression in a striated duct. (B) Gall bladder. (C) Pancreas. In (B) arrowhead indicates a mast cell. Scale
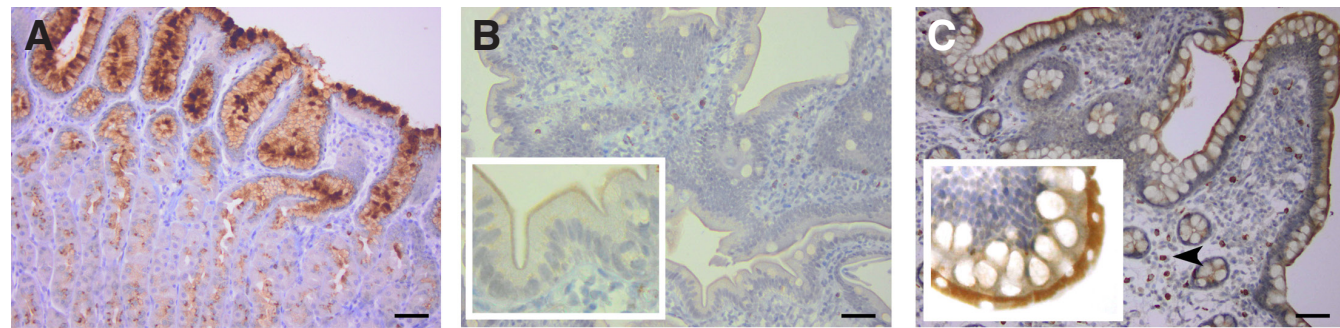

bar: $50 \mu \mathrm{m}$
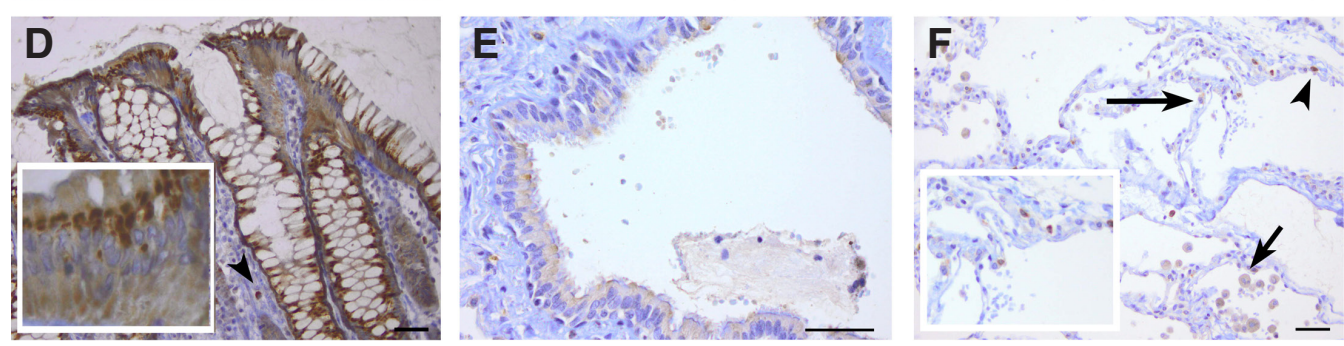

Fig. 3. Rab27B immunostaining in adult tissues with protective mucus barrier. (A) Stomach. (B) Duodenum. (C) Ileum. (D) Colon. (E) Bronchial epithelium. (F) Alveoli. In (F) large arrow, type 2 alveolar pneumocytes, small arrow, macrophage. In (C, $\mathbf{D}, \mathbf{F})$ arrowheads indicate mast cells. In (B, $\mathbf{C}, \mathbf{D})$ insets indicate Rab27B staining in the surface epithelium. In (F) the inset zooms in on type 2 alveolar pneumocytes and mast cells. Scale bar: 50 um.

luminal side of mucus-secreting cells of the surface epithelium and gastric pits (Fig. 3A). In the deep glandular structure consisting of coiled glands, Rab27B localizes at the luminal side. The Rab27B staining pattern in gastric acid-secreting parietal cells varies from a diffuse cytoplasmic localization to concentrated perinuclear signals. Rab27B localizes to tubulovesicular membranes in parietal cells and may play a role in stimulation-induced membrane recruitment of the $\mathrm{H}+/ \mathrm{K}+\mathrm{ATP}$ ase proton pump (Suda et al., 2011). Pepsinogen-secreting chief cells exhibit a diffuse Rab27B cytoplasmic staining (Fig. 3A). In the duodenum and ileum epithelia, lined by absorptive cells and interspersed goblet cells, Rab27B staining is detected at the lateral and luminal interfaces (Fig. 3 B,C). Interestingly, in the small intestine, Rab27B is less abundant at the base columnar crypts. Absorptive cells and goblet epithelial cells of the colon mucosa demonstrate a strong cytoplasmic Rab27B signal (Fig. 3D). In absorptive cells Rab27B is localized apically according to the basal position of the nuclei, whereas in the goblet cells the Rab27B signal is confined at the basolateral interface, under the apical mucus vacuole. Similarly, Rab27A is present in mucin-secreting cells of the gastrointestinal tract (Tolmachova et al., 2004). In the lamina propria, Rab27B is abundantly detected in the cytoplasm of mast cells.

In the bronchial epithelium Rab27B is detected in the numerous ciliated cells and the scattered goblet cells (Fig. 3E). Both type 2 alveolar pneumocytes and columnar alveolar lining cells involved in surfactant secretions display a cytoplasmic Rab27B expression (Fig. 3F). In contrast, type 1 alveolar pneumocytes and large and flat alveolar lining cells do not express Rab27B protein. Alveolar macrophages and mast cells in the lung parenchyma are Rab27B positive (Fig. 3F). Loss of Rab27B function results in abnormal

lung epithelium structure in mice, characterized by atrophy (Bolasco et al., 2011). Rab3D has been detected in type 2 alveolar pneumocytes, although its precise function remains unknown (van Weeren et al., 2004).

\section{Thrombus formation, allergy and inflammation}

In bone marrow, only one type of haematopoietic cell, namely the megakaryocytes, showed abundant and uniform Rab27B staining in the cytoplasm (Fig. 4A,B). Consistently, blood analysis revealed Rab27B expression in platelets but not in myeloid and erythroid cells (data not shown). In platelets, Rab27B expression and function has been described in great detail (Barral et al., 2002, Kondo et al., 2006, Tiwari et al., 2003, Tolmachova et al., 2007). Mature megakaryocytes are converted in proplatelets via the generation of long cytoplasmic extensions coordinated by Rab27B. Proplatelets subsequently generate functional platelets (Tiwari et al., 2003). It is proposed that Rab27B controls the cytoskeletal-mediated transport
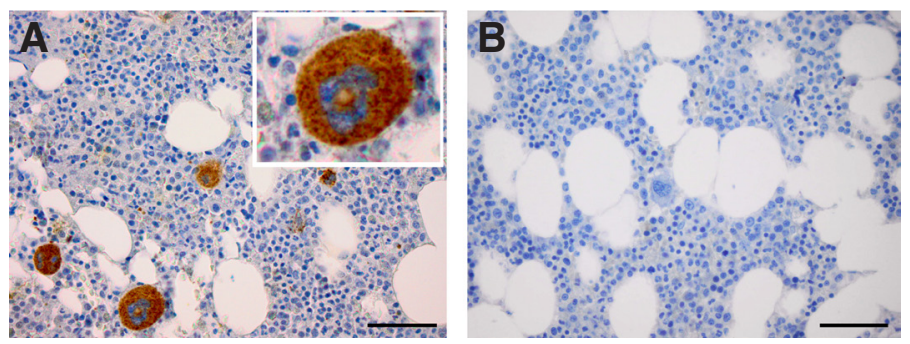

Fig. 4. Rab27B immunostaining in bone marrow (A) and a control slide of bone marrow omitting the primary anti-Rab27B antibody with absence of megakaryocyte staining (B). In (A) the inset indicates a megakaryocyte. Scale bar: $50 \mu \mathrm{m}$. 
TABLE 1

Rab27B PROTEIN DISTRIBUTION IN DEVELOPING AND DIFFERENTIATED TISSUES DETERMINED BY IMMUNOHISTOCHEMISTRY

\begin{tabular}{|c|c|c|c|c|c|c|}
\hline \multirow[b]{2}{*}{ System } & \multirow[b]{2}{*}{ Organ } & \multirow[b]{2}{*}{ Cell type } & \multicolumn{2}{|c|}{ Fetal } & \multicolumn{2}{|c|}{ Adult } \\
\hline & & & Localization & Intensity & Localization & Intensity \\
\hline \multirow[t]{10}{*}{ Alimentary tract } & Salivary & Serous acinar & $\mathrm{Nd}$ & & Cell-cell contacts & ++ \\
\hline & & striated ducts & $\mathrm{Nd}$ & & Luminal & +++ \\
\hline & Esophagus & Squamous epithelium & & - & & - \\
\hline & Stomach & Mucus secreting & Diffuse cytoplasmic & + & Luminal & ++++ \\
\hline & & Chief cells & & - & Diffuse cytoplasmic & ++ \\
\hline & & Parietal cells & & - & $\begin{array}{l}\text { Diffuse cytoplasmic to } \\
\text { concentrated perinuclear }\end{array}$ & ++ \\
\hline & Small intestine & Absorptive cells & Diffuse cytoplasmic & + & Luminal & ++ \\
\hline & & Goblet cells & Diffuse cytoplasmic & + & Luminal & ++ \\
\hline & Colon & Absorptive cells & & - & Luminal+cytoplasmic & ++++ \\
\hline & & Goblet cells & & - & Luminal+cytoplasmic & ++++ \\
\hline \multirow[t]{5}{*}{ Associated alimentary tract } & Liver & & & - & & - \\
\hline & Gall bladder & Columnar epithelial cells & Diffuse cytoplasmic & + & Luminal & ++++ \\
\hline & pancreas & Acinar & $\begin{array}{l}\text { Diffuse cytoplasmic to } \\
\text { concentrated perinuclear }\end{array}$ & + & Diffuse cytoplasmic & ++ \\
\hline & & Pancreatic ducts & Luminal & + & Luminal & +++ \\
\hline & & Endocrine & & - & & - \\
\hline \multirow[t]{4}{*}{ Respiratory } & Lung & Ciliated cells & & - & Diffuse cytoplasmic & + \\
\hline & & Goblet cells & & - & Diffuse cytoplasmic & + \\
\hline & & Type I alveolar pneumocytes & & - & & - \\
\hline & & Type II alveolar pneumocytes & & - & Diffuse cytoplasmic & + \\
\hline \multirow[t]{5}{*}{ Haematopoietic } & Spleen & & $\mathrm{Nd}$ & & & - \\
\hline & Lymph node & & $\mathrm{Nd}$ & & & - \\
\hline & Bone marrow & megakaryocytes & $\mathrm{Nd}$ & & Granular cytoplasmic & ++++ \\
\hline & & Myeloid & $\mathrm{Nd}$ & & & - \\
\hline & & Erythroid & $\mathrm{Nd}$ & & & - \\
\hline \multirow[t]{9}{*}{ Reproductive } & Mammary gland & Basal myoepithelial & $\mathrm{Nd}$ & & & - \\
\hline & & Luminal epithelial cells & $\mathrm{Nd}$ & & Luminal & ++++ \\
\hline & Ovarium & Oocytes & Cytoplasmic & + & Cytoplasmic & + \\
\hline & Prostate & Basal cells & $\mathrm{Nd}$ & & & - \\
\hline & & Columnar epithelial cells & $\mathrm{Nd}$ & & Luminal & ++++ \\
\hline & Testis & Sertoli cells & & - & & - \\
\hline & & Spermatid & & - & Acrosome & ++++ \\
\hline & & Myoid cells & & - & & - \\
\hline & & Leydig cells & Cytoplasmic & + & Cytoplasmic & ++ \\
\hline \multirow[t]{3}{*}{ Soft tissues } & Skeletal & Skeletal muscle cells & & - & & - \\
\hline & Smooth muscle & Smooth muscle cells & & - & & - \\
\hline & cardiac & Cardiomyocytes & & - & & - \\
\hline \multirow[t]{5}{*}{ All organs } & & Fibroblasts & & - & & - \\
\hline & & Adipocytes & & - & & - \\
\hline & & Endothelial cells & & - & & - \\
\hline & & Mast cells & Cytoplasmic & + & Granular cytoplasmic & ++++ \\
\hline & & macrophages & Cytoplasmic & + & Cytoplasmic & ++ \\
\hline
\end{tabular}

Scales of,,,,-++++++++++ were judged as negative, weakly positive, moderately positive, strongly positive and very strongly positive staining, respectively. Nd, not determined.

and distribution of dense granules during platelet activation and proplatelet formation in megakaryocytes. Platelet aggregation and thrombus formation is supported and enhanced by the release of a number of substances such as serotonin, histamine, ATP, interleukin $1-\beta$ and vascular endothelial growth factor from dense granules stored within platelets. The role of Rab27B in allergy and inflammation is highlighted by recent studies showing that Rab27B is localized to histamine and serotonin-containing secretory granules in mast cells, and to azurophilic primary granules in neutrophils, respectively (Johnson et al., 2010, Mizuno et al., 2007). The activation of the high-affinity immunoglobulin $\mathrm{E}(\mathrm{lg} \mathrm{E})$ receptor induces exocytosis of the granules, resulting in the release of allergy and inflammatory mediators. Also Rab3 family proteins and Rab27A are present on mast cell secretory granules (Mizuno et al., 2007). Rab27A is detected on primary, secondary and tertiary granules in neutrophils (Herrero-Turrion et al., 2008).

\section{Reproductive tissue}

In the mammary gland Rab27B is expressed and concentrated at the luminal surface of the epithelial cell layer (Fig. 5A). The myoepithelial cell layer and the collagenous fibroblast-rich stroma have no detectable Rab27B protein. In the ovarian stroma no Rab27B expression is detected. Oocytes display a weak cytoplasmic positivity for Rab27B (Fig. 5B). 

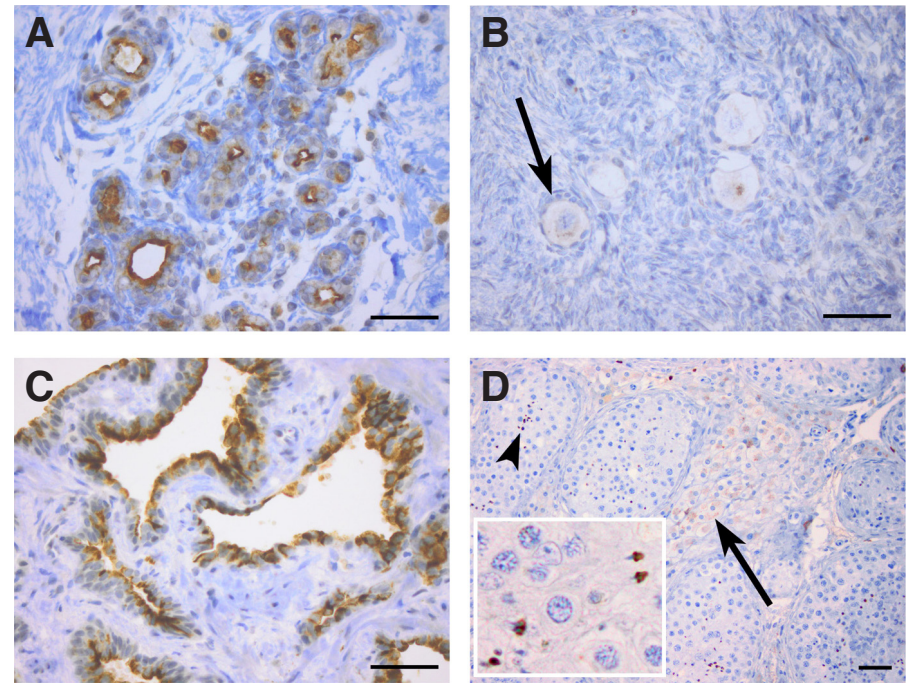

Fig. 5. Analysis of Rab27B protein in (A) mammary gland; (B) ovary (arrow, oocyte); (C) prostate gland and (D) testis (arrow, Leydig cells; arrowhead: spermatids). In (D) the inset zooms in on spermatids. Scale bar: $50 \mu \mathrm{m}$.

The secretory cells of the prostate provide a nutritive and protective medium consisting of proteolytic enzymes, citric acid, acid phosphatase and lipids for the spermatozoa. In the basal cell layer, we observe a weak cytoplasmic Rab27B staining (Fig. 5C) while the stroma is Rab27B negative. In the secretory epithelial cell layer, Rab27B expression is concentrated at the luminal side but also a strong cytoplasmic staining is observed. In the testis Rab27B protein is not detectable in Sertoli cells (Fig. 5D). Spermatogenic cells show a strong Rab27B expression in the acrosome of spermatids. The myoid smooth muscle-like cells that surround the basal lamina of the seminiferous tubules show no Rab27B expression. In the interstitial connective tissue the Leydig cells which secrete testosterone and related androgens, show a weak cytoplasmic Rab27B expression (Fig. 5D). Rab27B is implicated in intramanchette transport during spermiogenesis (Hayasaka et al., 2008).

\section{Discussion}

Rab27B does not appear to be critically involved in normal development but is expressed in a broad variety of differentiated secretory cell types.

Fetal tissue array analysis suggests that: 1) The mucosal barrier is absent at the epithelial surface of the fetal bronchus and alimentary tract; 2) The dispersed Rab27B expression in the exocrine cells of the pancreas will likely spread out progressively during gestation to contribute to digestive enzyme secretions. Similar dispersed staining patterns are observed for lipase labeling in the developing human pancreas (Carrere et al., 1992); 3) A critical role for Rab27B in development is not established from our study and other reports since Rab27B-null mice and naturally occurring Rab27B animal mutants exhibit no gross abnormalities in development, behavior and reproduction (Gomi et al., 2007, Tolmachova et al., 2004).

The polarization of Rab27B toward the apical/luminal side of secretory cells coincides with the localization of secretory granules. Our observations are largely consistent with previous analysis of
Rab27B-driven LacZ expression in a mouse model (Gomi et al., 2007). The complex pattern of Rab27B expression (Table 1) indicates that dysregulation of Rab27B-mediated secretion can have profound implications for disease pathology, including cancer. Indeed, increased expression of Rab27B delivers crucial signals for invasion, tumor size, and metastasis of various ER-positive breast cancer cell lines, both in cell culture and in xenograft mouse models (Hendrix et al., 2010b). The presence of Rab27B protein is associated with a low degree of differentiation and lymph node metastasis in ER-positive primary breast cancer. Rab27B is a potential key marker for stratification, prognosis and treatment of early stage ER-positive breast cancers which are more invasive and tend to metastasize more frequently (Hendrix et al., 2010a).

In conclusion, Rab GTPase mediated vesicle exocytosis is efficiently implemented by epithelial cells and bone marrow-derived cells with a secretory function. These data are of (1) biological interest, for the study of cell-type specific Rab27B function, (2) clinical interest, to gain insight in the potential role of Rab27B in different pathologies, and (3) therapeutic interest, to unravel the potential for therapeutic targeting of Rab27B function as suggested in allergy (Mizuno et al., 2007), ER $\alpha$-positive breast tumors (Hendrix et al., 2010b, Wright et al., 2009) and to predict possible side or toxic effects as a consequence of this therapeutic targeting.

\section{Materials and Methods}

\section{Immunohistochemistry}

Tissue arrays of normal human fetal tissues were obtained from US Biomax (BE01014 and BE01015; Rockville, MD). De-paraffinization, hydratation and antigen-retrieval were performed according to the manufacturer's guidelines. Sections $(4 \mu \mathrm{m})$ were cut from non-commercial paraffin-embedded blocks of human adult normal tissues (from each tissue $n=3$ ). Sections were fixed in neutral buffered $4 \%$ formaldehyde and de-paraffinized with EZ Prep ${ }^{\mathrm{TM}}$ Concentrate (Ventana Medical Systems, Tucson, AZ). Subsequently slides were loaded in the Ventana autostainer (Benchmark XT, Ventana Medical Systems) and stained with the Ultraview Universal DAB detection system (Ventana Medical Systems) according to the manufacturer's instructions. Antigen retrieval was performed using EDTA pre-treatment (Ventana Medical Systems). Sections were then incubated with a well-characterized and highly specific anti-Rab27B rabbit polyclonal antibody diluted at $1 / 500$, during 32 min at $37^{\circ} \mathrm{C}$ (Hendrix et al., 2010b). Nuclei were counterstained with Mayer's haematoxylin. All directly compared images are from slides processed in a single experiment with a matched negative control (purified rabbit immunoglobulin lgG). Four independent observers (two pathologists) performed microscopic evaluation of blind-coded sections.

\section{Conflict of interest}

There is no conflict of interest to disclose.

\section{Acknowledgements}

This work was supported by the Intramural Research Program of the National Human Genome Research Institute, Foundation against Cancer, Spearhead Oncology of Ghent University Hospital, and a postdoctoral grant from Special Research Fund of Ghent University $(A H)$.

\section{References}

BARRAL, D.C., RAMALHO, J.S., ANDERS, R., HUME, A.N., KNAPTON, H.J., TOLMACHOVA, T., COLLINSON, L.M., GOULDING, D., AUTHI, K.S. and SEABRA, M.C. (2002). Functional redundancy of Rab27 proteins and the pathogenesis of Griscelli syndrome. J Clin Invest 110: 247-257. 
BOLASCO, G., TRACEY-WHITE, D.C., TOLMACHOVA, T., THORLEY, A.J., TETLEY, T.D., SEABRA, M.C. and HUME, A.N. (2011). Loss of Rab27 function results in abnormal lung epithelium structure in mice. Am J Physiol Cell Physiol 300: C466-476.

CARRERE, J., FIGARELLA-BRANGER, D., SENEGAS-BALAS, F., FIGARELLA, C. and GUY-CROTTE, O. (1992). Immunohistochemical study of secretory proteins in the developing human exocrine pancreas. Differentiation 51: 55-60.

CHEN, X., LI, C., IZUMI, T., ERNST, S.A., ANDREWS, P.C. and WILLIAMS, J.A. (2004). Rab27b localizes to zymogen granules and regulates pancreatic acinar exocytosis. Biochem Biophys Res Commun 323: 1157-1162.

CHEN, Y., GUO, X., DENG, F.M., LIANG, F.X., SUN, W., REN, M., IZUMI, T., SABATINI, D.D., SUN, T.T. and KREIBICH, G. (2003). Rab27b is associated with fusiform vesicles and may be involved in targeting uroplakins to urothelial apical membranes. Proc Natl Acad Sci USA 100: 14012-14017.

CONNER, S.D. and WESSEL, G.M. (2001). Syntaxin, VAMP, and Rab3 are selectively expressed during sea urchin embryogenesis. Mol Reprod Dev 58: 22-29.

FUKUDA, M. (2008). Regulation of secretory vesicle traffic by Rab small GTPases. Cell Mol Life Sci 65: 2801-2813.

GOMI, H., MORI, K., ITOHARA, S. and IZUMI, T. (2007). Rab27b is expressed in a wide range of exocytic cells and involved in the delivery of secretory granules near the plasma membrane. Mol Biol Cell 18: 4377-4386.

GROSSHANS, B.L., ORTIZ, D. and NOVICK, P. (2006). Rabs and their effectors: achieving specificity in membrane traffic. Proc Nat/Acad SciUSA 103: 11821-11827.

HAYASAKA, S., TERADA, Y., SUZUKI, K., MURAKAWA, H., TACHIBANA, I., SANKAI, T., MURAKAMI, T., YAEGASHI, N. and OKAMURA, K. (2008). Intramanchette transport during primate spermiogenesis: expression of dynein, myosin $\mathrm{Va}$, motor recruiter myosin Va, VIla-Rab27a/b interacting protein, and Rab27b in the manchette during human and monkey spermiogenesis. Asian J Androl 10: 561-568.

HENDRIX, A., BRAEMS, G., BRACKE, M., SEABRA, M.C., GAHL, W.A., DE WEVER, O. and WESTBROEK, W. (2010a). The secretory small GTPase Rab27B as marker for breast cancer progression. Oncotarget 1: 304-308.

HENDRIX, A., MAYNARD, D., PAUWELS, P., BRAEMS, G., DENYS, H., VAN DEN BROECKE, R., LAMBERT, J., VAN BELLE, S., COCQUYT, V., GESPACH, C. et al., (2010b). Effect of the secretory small GTPase Rab27B on breast cancer growth, invasion, and metastasis. J Natl Cancer Inst 102: 866-880.

HENDRIX, A., WESTBROEK, W., BRACKE, M. and DE WEVER, O. (2010c). An ex(o)citing machinery for invasive tumor growth. Cancer Res 70: 9533-9537.

HERRERO-TURRION, M.J., CALAFAT, J., JANSSEN, H., FUKUDA, M. and MOLLINEDO, F. (2008). Rab27a regulates exocytosis of tertiary and specific granules in human neutrophils. J Immunol 181: 3793-3803.

IMAI, A., YOSHIE, S., NASHIDA, T., SHIMOMURA, H. and FUKUDA, M. (2004). The small GTPase Rab27B regulates amylase release from rat parotid acinar cells. J Cell Sci 117: 1945-1953.

JOHNSON, J.L., BRZEZINSKA, A.A., TOLMACHOVA, T., MUNAFO, D.B., ELLIS B.A., SEABRA, M.C., HONG, H. and CATZ, S.D. (2010). Rab27a and Rab27b regulate neutrophil azurophilic granule exocytosis and NADPH oxidase activity by independent mechanisms. Traffic 11: 533-547.

KONDO, H., SHIRAKAWA, R., HIGASHI, T., KAWATO, M., FUKUDA, M., KITA, T. and HORIUCHI, H. (2006). Constitutive GDP/GTP exchange and secretion-dependent GTP hydrolysis activity for Rab27 in platelets. J Biol Chem 281: 28657-28665.

LEUNG, K.F., BARON, R. and SEABRA, M.C. (2006). Thematic review series: lipid posttranslational modifications. geranylgeranylation of Rab GTPases. J Lipid Res 47: 467-475.

MIZUNO, K., TOLMACHOVA, T., USHAKOV, D.S., ROMAO, M., ABRINK, M., FERENCZI, M.A., RAPOSO, G. and SEABRA, M.C. (2007). Rab27b regulates mast cell granule dynamics and secretion. Traffic 8: 883-892.

OHNISHI, H., ERNST, S.A., WYS, N., MCNIVEN, M. and WILLIAMS, J.A. (1996). Rab3D localizes to zymogen granules in rat pancreatic acini and other exocrine glands. Am J Physiol 271: G531-538.

OHNISHI, H., SAMUELSON, L.C., YULE, D.I., ERNST, S.A. and WILLIAMS, J.A. (1997). Overexpression of Rab3D enhances regulated amylase secretion from pancreatic acini of transgenic mice. J Clin Invest 100: 3044-3052.

PIPERHANLEY, K., HEARN, T., BERRY, A., CARVELL, M.J., PATCH, A.M., WILLIAMS, L.J., SUGDEN, S.A., WILSON, D.I., ELLARD, S. and HANLEY, N.A. (2010). In vitro expression of NGN3 identifies RAB3B as the predominant Ras-associated GTP-binding protein 3 family member in human islets. J Endocrinol 207: 151-161.

SCHONN, J.S., VAN WEERING, J.R., MOHRMANN, R., SCHLUTER, O.M., SUDHOF, T.C., DE WIT, H., VERHAGE, M. and SORENSEN, J.B. (2010). Rab3 proteins involved in vesicle biogenesis and priming in embryonic mouse chromaffin cells. Traffic 11: 1415-1428.

STENMARK, H. (2009). Rab GTPases as coordinators of vesicle traffic. Nat Rev Mol Cell Biol 10: 513-525.

SUDA, J., ZHU, L., OKAMOTO, C.T. and KARVAR, S. (2011). Rab27b localizes to the tubulovesicle membranes of gastric parietal cells and regulates Acid secretion. Gastroenterology 140: 868-878.

TIWARI, S., ITALIANO, J.E., JR., BARRAL, D.C., MULES, E.H., NOVAK, E.K., SWANK, R.T., SEABRA, M.C. and SHIVDASANI, R.A. (2003). A role for Rab27b in NF-E2dependent pathways of platelet formation. Blood 102: 3970-3979.

TOLMACHOVA, T., ABRINK, M., FUTTER, C.E., AUTHI, K.S. and SEABRA, M.C (2007). Rab27b regulates number and secretion of platelet dense granules. Proc Natl Acad Sci USA 104: 5872-5877.

TOLMACHOVA, T., ANDERS, R., STINCHCOMBE, J., BOSSI, G., GRIFFITHS, G.M., HUXLEY, C. and SEABRA, M.C. (2004). A general role for Rab27a in secretory cells. Mol Biol Cell 15: 332-344.

VAN WEEREN, L., DE GRAAFF, A.M., JAMIESON, J.D., BATENBURG, J.J. and VALENTIJN, J.A. (2004). Rab3D and actin reveal distinct lamellar body subpopulations in alveolar epithelial type II cells. Am J Respir Cell Mol Biol 30: 288-295.

VETTER, I.R. and WITTINGHOFER, A. (2001). The guanine nucleotide-binding switch in three dimensions. Science 294: 1299-1304.

WASELlE, L., COPPOLA, T., FUKUDA, M., IEZZI, M., EL-AMRAOUI, A., PETIT, C. and REGAZZI, R. (2003). Involvement of the Rab27 binding protein Slac2c/ MyRIP in insulin exocytosis. Mol Biol Cell 14: 4103-4113.

WRIGHT, P.K., MAY, F.E., DARBY, S., SAIF, R., LENNARD, T.W. and WESTLEY, B.R. (2009). Estrogen regulates vesicle trafficking gene expression in EFF-3, EFM-19 and MCF-7 breast cancer cells. Int J Clin Exp Pathol 2: 463-475.

YI, Z., YOKOTA, H., TORII, S., AOKI, T., HOSAKA, M., ZHAO, S., TAKATA, K., TAKEUCHI, T. and IZUMI, T. (2002). The Rab27a/granuphilin complex regulates the exocytosis of insulin-containing dense-core granules. Mol Cell Biol 22: 1858-1867.

ZHAO, S., TORII, S., YOKOTA-HASHIMOTO, H., TAKEUCHI, T. and IZUMI, T. (2002). Involvement of Rab27b in the regulated secretion of pituitary hormones. Endocrinology 143: 1817-1824. 


\section{Further Related Reading, published previously in the Int. J. Dev. Biol.}

Exosome signaling in mammary gland development and cancer

An Hendrix and Alistair N. Hume

Int. J. Dev. Biol. (2011) 55: 879-887

Rab11 is required for cell adhesion, maintenance of cell shape and actin-cytoskeleton organization during Drosophila wing development

Tanmay Bhuin and Jagat K. Roy

Int. J. Dev. Biol. (2011) 55: 269-279

Spa-1 regulates the maintenance and differentiation of human embryonic stem cells Young-Jin Lee, Hee-Young Nah, Seok-Ho Hong, Ji-Won Lee, llkyung Jeon, Jhang Ho Pak, Joo-Ryung Huh, Sung-Hoon Kim, Hee-Dong Chae, Byung-Moon Kang, Chul Geun Kim and Chung-Hoon Kim

Int. J. Dev. Biol. (2008) 52: 43-53

Analysis of the role of the Rac/Cdc42 GTPases during planar cell polarity generation in Drosophila

Silvia Muñoz-Descalzo, Azucena Gómez-Cabrero, Marek Mlodzik and Nuria Paricio

Int. J. Dev. Biol. (2007) 51: 379-388

Expression of ADP-ribosylation factor (ARF)-like protein 6 during mouse embryonic development

Tatsuyuki Takada, Keiko lida, Hiroshi Sasaki, Masanori Taira and Hiroshi Kimura

Int. J. Dev. Biol. (2005) 49: 891-894

Vesicular transport and kidney development

S Lehtonen, E Lehtonen and V M Olkkonen

Int. J. Dev. Biol. (1999) 43: 425-433

5 yr ISI Impact Factor $(2010)=2.961$

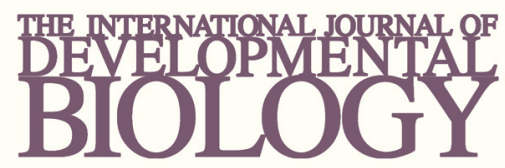

Volume 54 Nos. 6/7
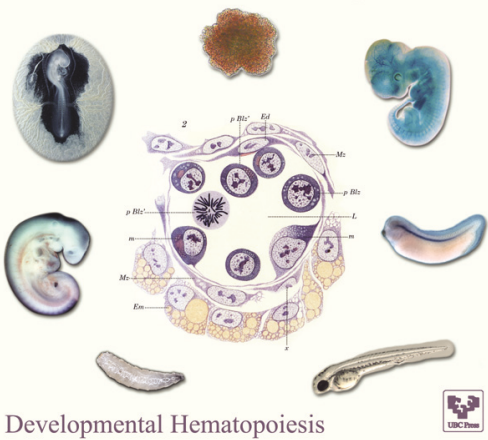
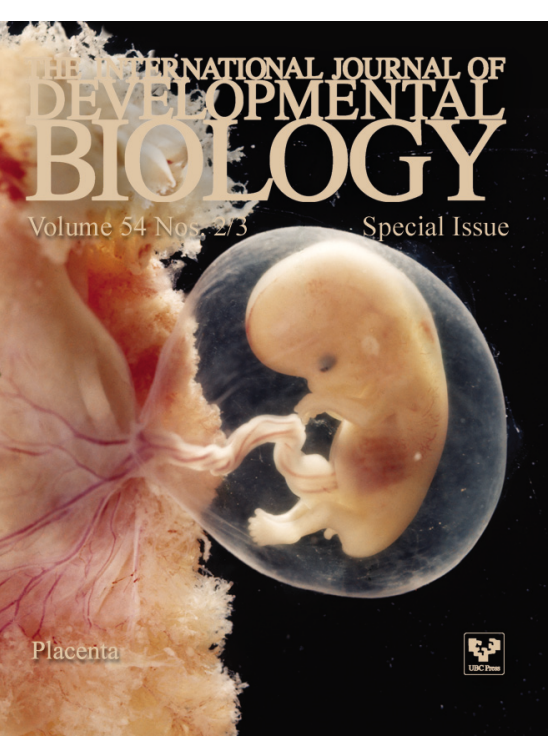
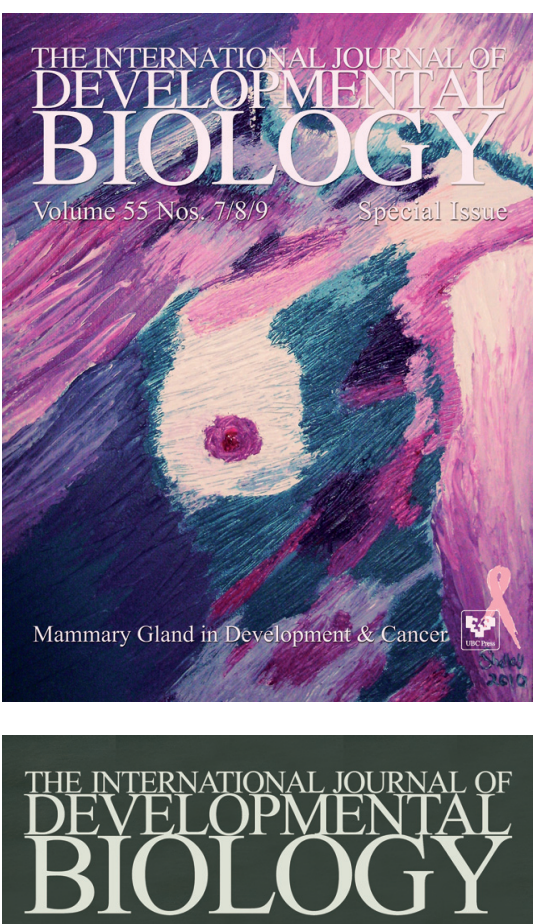

Volume 55 Nos. $4 / 5$

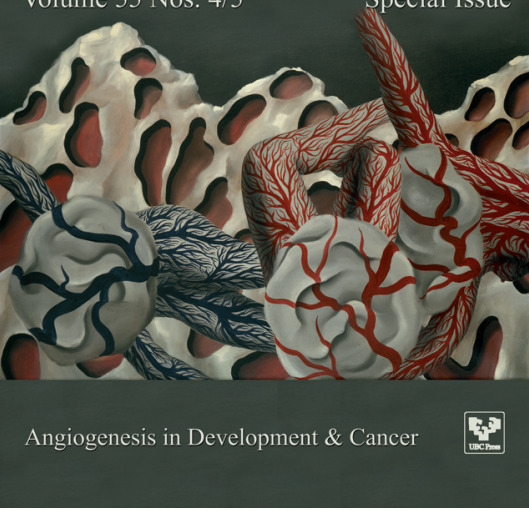

